\title{
PELATIHAN PEMBUATAN BIBIT STEK BATANG TANAMAN REHABILITASI DI DESA KARANGSARI KABUPATEN KUNINGAN
}

\author{
Yayan Hendrayana dan Agus Yadi Ismail \\ Fakultas Kehutanan Universitas Kuningan, Indonesia \\ E-mail : yayan.hendrayana@uniku.ac.id
}

\begin{abstract}
Ficus spp. is a plant that can play an important role in efforts to increase environmental conservation and forest productivity. One type is beunying (Ficus fistulosa) which is included in plant rehabilitation and restoration. Propagation of the Ficus plant is easiest to do by vegetative or stem cuttings. Therefore community service offers a solution in the form of making rehabilitation plant seeds through cuttings of Ficus fistulosa tree trunks. The hope is that by utilizing the rehabilitation tree that tastes in the Pasirbatang Block, this tourism mobilizing farmer group can produce rehabilitation plant seeds and increase the opinions of its members.
\end{abstract}

Keywords: Vegetative propagation, training, empowerment.

\begin{abstract}
Abstrak
Ficus spp. merupakan tanaman yang dapat berperan penting dalam upaya peningkatan konservasi lingkungan maupun produktivitas hutan. Salah satu jenis nya adalah beunying (Ficus fistulosa) merupakan yang termasuk ke dalam tanaman rehabilitasi dan restorasi. Perbanyakan tanaman Ficus yang paling mudah dilakukan adalah dengan cara vegetatif atau stek batang. Oleh karena itu pengabdian kepada masyarakat menawarkan solusi berupa cara pembuatan bibit tanaman rehabilitasi melalui stek batang pohon Ficus fistulosa. Harapannya adalah dengan memanfaatkan pohon rehabilitasi yang berasa di Blok Pasirbatang ini kelompok tani penggerak pariwisata ini dapat menghasilkan bibit tanaman rehabilitasi serta meningkatkan pendapatn para anggotanya.
\end{abstract}

Kata kunci : Perbanyakan vegetatif, pelatihan, pemberdayaan

\section{PENDAHULUAN}

Kawasan Blok Karangsari Taman Nasional Gunung Ciremai (TNGC) merupakan salah satu dari zona rehabilitasi yang mempunyai tutupan lahan sebagian besar adalah tegakan Pinus merkusii. Berdasarkan hasil wawancara dengan masyarakat sejak Tahun 2014 kegiatan rehabilitasi pada blok ini telah dilakukan dengan menanam beberapa jenis tanaman rehabilitasi salah satunya adalah jenis beunying (Ficus fistulosa) yang merupakan marga dari beringin-beringinan. Ficus spp merupakan tanaman yang dapat berperan penting dalam upaya peningkatan konservasi lingkungan maupun produktivitas hutan. Ficus adalah genus tanaman yang paling penting bagi kehidupan hewan tropis pemakan buah (Sreekar, et al. 2010, Shanahan et al. 2001). Salah satu jenis nya adalah beunying (Ficus fistulosa) merupakan yang termasuk ke dalam tanaman rehabilitasi dan restorasi (Kementrian Kehutanan, 2014).

Berdasarkan hasil penelitian yang dilakukan di laboratorium rumah kaca Fakultas Kehutanan Universitas Kuningan bagian ujung stek batang Ficus fistulosa merupakan bagian yang tercepat tumbuh dari beberapa perlakuan. Oleh sebab itu penulis akan melakukan kegiatan pengabdian pada masyarakat dengan tema "Pembuatan bibit stek batang tanaman rehabilitasi di Desa Karangsari Kecamatan Darma Kabupaten Kuningan.

Dalam upaya rehabilitasi lahan dan hutan kendala yang sering di hadapi adalah ketersediaan bibit tanaman rehabilitasi yang siap tanam. Sampai saat ini kelompok tani 
penggerak pariwisata hanya memanfaatkan bibit tanaman rehabilitasi dari penyedia bibit (pedagang), hal ini terjadi karena para petani mempunyai keterbatasan pengetahuan dalam pembuatan bibit tanaman khususnya yang berasal dari perbanyakan vegetatif (stek). Penelitian awal yang telah dilakukan menunjukkan bahwa stek batang Ficus fistulosa yang berasal dari ujung cabang mempunyai potensi pertumbuhan yang baik disbanding asal stek lainnya. Oleh karena itu, pengabdian kepada masyarakat ini menawarkan solusi berupa pembuatan bibit stek batang Ficus fistulosa kemudian hasilnya transfer informasi kepada masyarakat berupa dilaksanakannya penyuluhan tentang pembuatan stek batang tanaman rehabilitasi.

Luaran yang dihasilkan dari kegiatan pengabdian kepada masyarakat ini adalah diperolehnya pengetahuan tentang cara membuat bibit stek batang tanaman rehabilitasi. Luaran lainnya adalah publikasi jurnal. Rencana capaian luaran terbagi menjadi 2 tahap yaitu rencana jangka pendek dan jangka panjang. Target untuk jangka pendek bisa diselesaikan pada akhir Tahun 2019 yaitu tersedianya bibit stek batang tanaman rehabilitasi untuk kegiatan penanaman pada musim penghujan.. Target jangka panjangnya pada tahun 2020, masyarakat Desa Karangsari sudah melaksanakan produksi bibit tanaman rehabilitasi dan dapat dipasarkan..

Dampak sosial dengan adanya pembuatan bibit stek batang tanaman rehabilitasi ini melalui penyuluhan dan pelatihan dapat terlaksana. Masyarakat yang terlibat akan mempunyai pengetahuan dan secara mandiri akan membuat bibit stek tanaman rehabilitasi guna keperluan rehabilitasi ataupun untuk diperjualbelikan.

\section{METODE PELAKSANAAN}

Kegiatan ini dilakukan di Desa Karangsari yang berbatasan langsung dengan Taman Nasional Gunung Ciremai.. Lama kegiatan sekitar 3 bulan, mulai bulan Agustus hingga Oktober tahun 2019. Kegiatan diawali dengan konsolidasi dan sosialisasi dengan mitra dan diakhiri dengan penyusunan laporan

\section{Pendekatan yang Ditawarkan}

Pendekatan yang ditawarkan dalam kegiatan ini adalah melakukan melakukan pelatihan dan mempraktekkan pembuatan bibit tanaman rehabilitasi. Adapun tahapan yang akan dilaksanakan sebagai berikut:

1. Pelatihan tentang pembuatan bibit stek batang

Pelatihan akan dilakukan oleh dosen Fakultas Kehutanan Universitas Kuningan, sehingga diharapkan masyarakat mendapatkan pengetahuan tentang cara pembuatan bibit stek batang.

Bahan-bahan yang digunakan dalam penelitian adalah stek beunying, larutan air kelapa, media tanam (tanah), dan polybag ukuran $10 \mathrm{~cm}$ x $15 \mathrm{~cm}$.

2. Praktek Pemeliharaan bibit stek

Praktek pemeliharaan bibit stek dilakukan oleh tim Fakultas Kehutanan kepada masyarakat dengan membuat bedengan pada persemaian kelompok tani. 


\section{Partisipasi Mitra dalam Pelaksanaan Program}

Kegiatan ini melibatkan masyarakat sebagai mitra Fakultas Kehutanan Universitas Kuningan dengan harapan semua kegiatan dapat berjalan sesuai dengan tujuan yang telah disepakati. Bentuk keterlibatan masyarakat dalam kegiatan ini berupa pelibatan dalam menyiapkan alat dan bahan yang akan dipraktekkan.

Kegiatan yang akan dilaksanakan ini merupakan kegiatan jangka panjang sehingga perlu dilakukan evaluasi pada setiap tahapan. Evaluasi program jangka pendek diharapkan masyarakat mampu membuat sirup pala sehingga evaluasi yang akan dilakukan adalah memantau setiap perkembangan yang terjadi di masyarakat dari hasil pelatihan. Target jangka panjangnya atau keberlanjutan program ini adalah masyarakat mampu memasarkan dan memperoleh perizinan produk hasil sehingga bisa meningkatkan penghasilan masyarakat.

\section{HASIL DAN PEMBAHASAN}

Pembuatan bibit stek batang terdiri dari beberapa tahap yaitu Tahap persiapan diantaranya adalah penyiapan zat pengatur tumbuh yang berasal dari air kelapa dan air dengan perbandingan 50\% yang disimpan dalam wadah/ember. Selanjutnya, dilakukannya pula penyiapan pada media tanam yang berasal dari tanah zona rehabilitasi. Selanjutnya media tanam yang berupa tanah ini dimasukan ke dalam polybag.

Perbanyakan tanaman Ficus dapat melalui biji, stek ataupun cangkok (Sobir dan Amalya, 2011). Morton (1987) menyatakan cara yang paling banyak digunakan untuk perbanyakan Ficus adalah dengan menggunakan stek. Keuntungan perbanyakan dengan cara stek adalah tanaman yang dihasilkan dari stek biasanya mempunyai persamaan dalam umur, ukuran tinggi, ketahanan terhadap penyakit dan dapat memperoleh tanaman yang sempurna yaitu tanaman yang telah mempunyai akar, batang dan daun dalam waktu yang relatif singkat juga dapat diperoleh jumlah bibit tanaman dalam jumlah banyak (Wudianto, 1996).
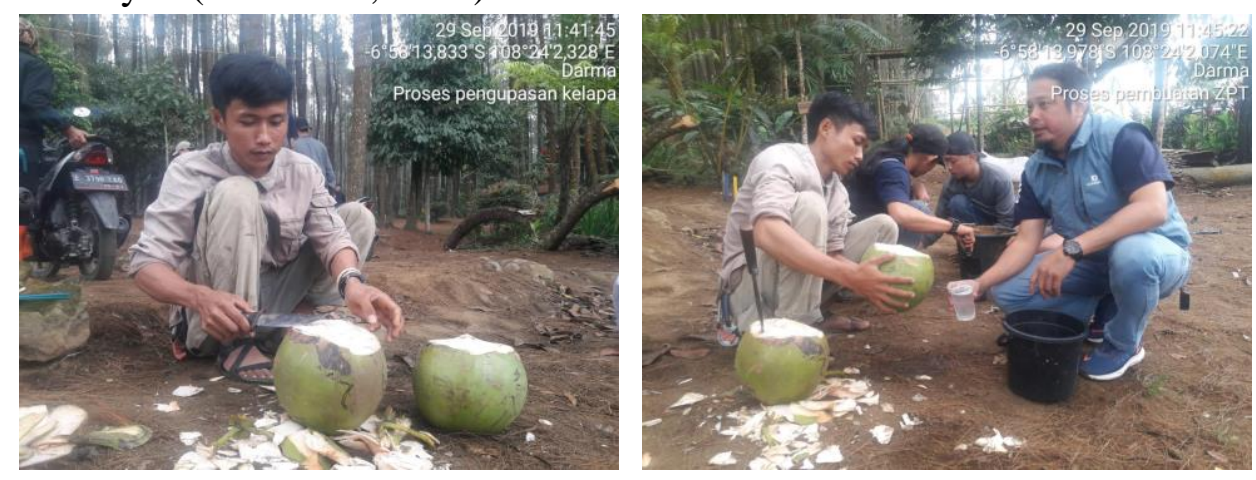

Gambar 1. Penyiapan zat pengatur tumbuh

Berdasarkan sumbernya, ZPT dapat diperoleh baik secara alami maupun sintetik. Umumnya ZPT alami langsung tersedia di alam dan berasal dari bahan organik, contohnya air kelapa, urin sapi, ekstrak buah-buahan (tomat, pisang ambon, alpukat) 
dan ekstrak kecambah tanaman (kecambah jagung dan kecambah kacang hijau) dan dari bagian tanaman lainnya (Nurlaeni dan Surya, 2015).
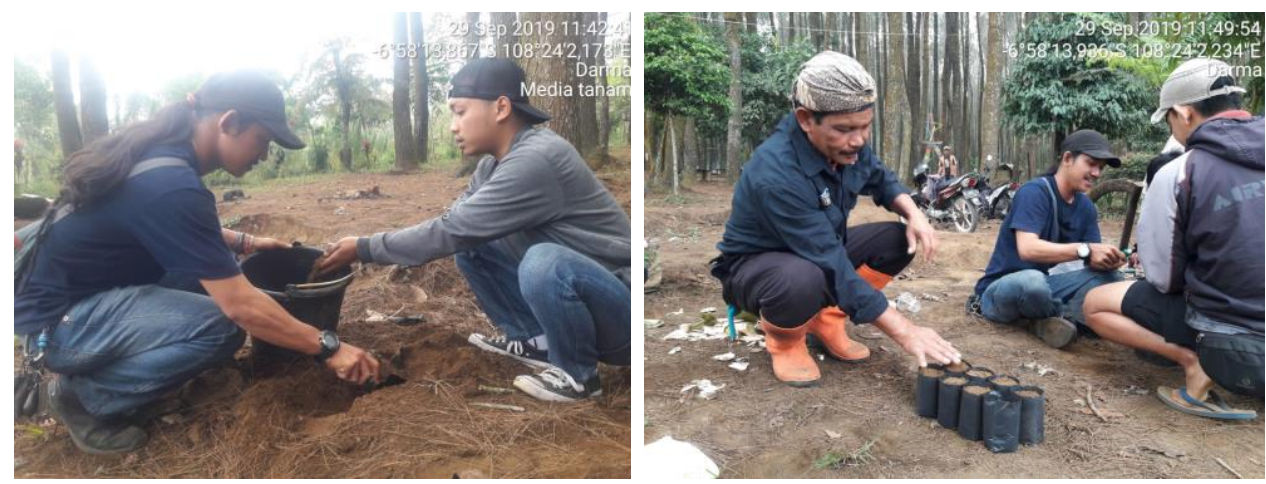

Gambar 2. Penyiapan media tanam

Stek diambil dari bagian tanaman muda. Bila tanaman tersebut sangat muda dan lunak maka transpirasi berlangsung cepat sehingga stek menjadi lemah dan akhirnya mati (Rochiman dan Harjadi, 1973). Menurut Wudianto (2002) cabang yang terlalu tua kurang baik digunakan sebagai bahan stek karena sulit untuk membentuk akar sehingga memerlukan waktu yang sangat lama untuk membentuk akar. Penggunaan stek yang muda lebih baik karena pertumbuhannya lebih cepat.
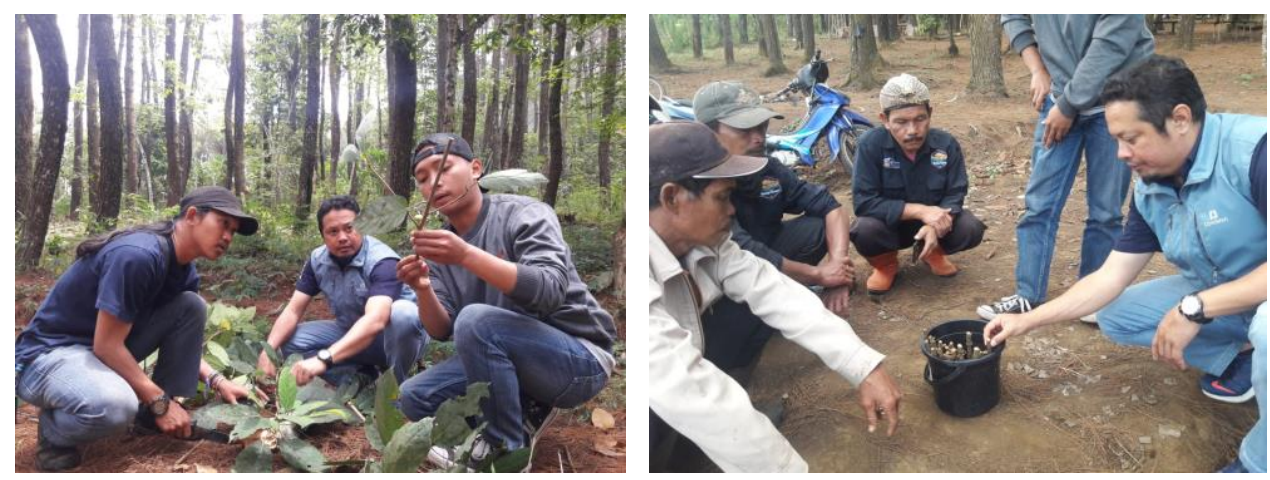

Gambar 3. Pemilihan stek batang dan perendaman

Menurut Morton (1987), cara perbanyakan tanaman ara dengan stek adalah dengan cara mengambil cabang dari tanaman ara yang berusia antara 2 sampai dengan 3 tahun, dengan ketebalan cabang antara 1.25-2 cm dan panjang batang stek antara 20-30 $\mathrm{cm}$. Penanaman harus dilakukan 24 jam setelah tanaman diambil dari indukan dan bagian dasar dari bahan stek diberikan hormone penumbuh akar agar membantu tumbuhnya akar. Perbanyakan tanaman Ficus dapat melalui biji, stek ataupun cangkok (Sobir dan Amalya, 2011). 

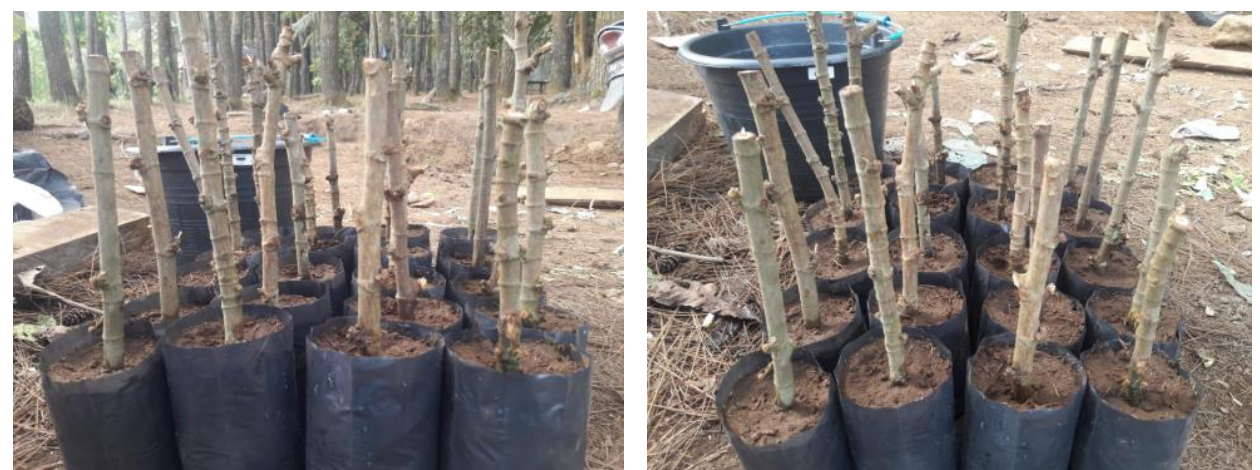

Gambar 4. Bibit stek batang

Selanjutnya Morton (1987) mengatkan cara yang paling banyak digunakan untuk perbanyakan ara adalah dengan menggunakan stek. Hartmann et al. (1990) membagi stek, antara lain, stek batang terdiri dari hardwood, semi hardwood, softwood dan herbaceus; stek daun serta stek akar. Stek batang ara sendiri termasuk ke dalam stek batang hardwood. Batang dengan getah putih. Ranting sering hampa. Stipula sekitar 10 mm, gundul. alternatif Daun, sederhana, penni-untuk tripli-urat, gundul. Buah berukuran $10 \mathrm{~mm}$ diameter, kuning-coklat, bulat, berdaging buah ara ditempatkan dalam bundel bersama ranting dan batang

\section{SIMPULAN}

Pembuatan bibit stek batang dari tanaman rehabilitasi mendapat respon yang cukup baik dari Kelompok Tani Penggerak Pariwisata Desa Karangsari Kecamatan Darma, meskipun baru pertama kalinya mendapatkan pengetahuan tersebut. Dengan adanya pengetahuan ini maka kebutuhan akan bibit tanaman rehabilitasi dikemudian hari akan tercukupi.

\section{SARAN}

Kegiatan pembuatan bibit stek batang harus dilakukan secara bekelanjutan dan melibatkan semua pihak sehingga hasilnya menjadi optimal serta peningkatan pemasaran terhadap konsumen-konsumen yang berpotensi sehingga pembuatan bibit stek batang selain dapat memenuhi kegiatan rehabilitasi juga dapat meningkatkan perekonomian masyarakat.

\section{UCAPAN TERIMA KASIH}

Ucapan terima kasih disampaikan kepada Universitas Kuningan melalui Lembaga Penelitian dan Pengabdian Kepada Masyarakat yang sudah memberikan bantuan dana untuk kegiatan pengbadian ini. Ucapan terima kasih juga disampaikan kepada Kelompok Tani Pariwisata Pasir Batang atas kerjasamanya dalam kegiatan ini serta Balai Taman Nasional Gunung Ciremai yang sudah memberikan ijin untuk melaksanakan kegiatan di dalam areal kerjanya 


\section{DAFTAR PUSTAKA}

Akinyele, A.O. (2010). Effects ofgrowth hormones, rooting media and leaf size on juvenile stem cuttings of Buchholzia coriacea Engler. Annals ofForest Research,53(2), 127-133

Hartmann, H. R., D. E. Kester, F. T. Davies and R. L. Geneve. 1990. Plant Propagation Principles and Practice. Sixth Edition. Prentice Hall, Inc. New Jersey. 559 p.

Kementrian Kehutanan, 2014. Buku Panduan Jenis-Jenis Tumbuhan Restorasi.

Morton, J. 1987. Fig. p. 47-50. In: Fruits of warm climates. Julia F. Morton, Miami, FL.

Nurlaeni, Y. dan M.I. Surya. 2015. Respon stek pucuk Camelia japonica terhadap pemberian zat pengatur tumbuh organik. Pros Sem Nas Masy BiodivIndon.1(5): 1211-1215.

Rochiman, K. \& Harjadi, S. (1973). Pembiakan vegetatif. Bogor: Departemen Agronomi Fakultas Pertanian, Institut Pertanian Bogor.

Sakai C danSubiaktoA. 2007. PedomanPembuatanStekJenis -Jenis Dipterokarpa denganKOFFCOSistem. Bogor. KerjasamaPuslitbangKomatsudan JICA.

Santoso, U. dan F. Nursandi. 2003. Kultur Jaringan Tanaman. Universitas Muhammadiyah Malang Press. Malang

Shanahan, M. Samson So, Compton S.G.and Corlett R. 2001. Fig-eating by vertebrate frugivores: a globalreview. Biol. Conservation. Vol. 76, pp. 529-572

Sobir dan M. Amalya. 2011. Bertanam 20 Buah Koleksi Eksklusif. Penerbit PT. Penebar Swadaya. Jakarta. 208 hal

Sreekar, R., N. T. P. Le dan R. D. Harrison, 2010. Vertebrate assemblage at a fruiting fig (Ficus caulocarpa) in Maliau basin, Malaysia. Tropical Conservation Science, 3: 218-227.

Sugiyono. 2010. Metode Penelitian Pendidikan Pendekatan Kuantitatif, kualitatif, dan R\&D. Bandung: Alfabeta

Toto Supartono dan Bambang Yudayana. 2019. Partisipasi Masyarakat dalam Peningkatan Pertumbuhan Permudaan Alami di Bumi Perkemahan Pasir Batang Taman Nasional Gunung Ciremai Desa Karangsari, Kecamatan Darma, Kuningan, Jawa Barat. Empowerment : Jurnal Pengabdian Masyarakat, e-ISSN 2598-2052 Vol. 02 Nomor 01. 2019.38-45.

Watijo. 2007. Uji Beberapa Jenis Zat Pengatur Tumbuh Pada Stek Lada (Piper Nigrum L.) Asal Sulur Panjat Dan Sulur Gantung. Skripsi STIPER Dharma Wacana Metro Lampung. 48 Halaman.

Wattimena,G. A. 1987. Zat Pengatur Tumbuh Tanaman.Buku. IPB.Bogor. $254 \mathrm{p}$

Weaver, R.J. 1972. Plant Growth Substances in Agriculture. Mc MillanPublishingCo Inc. New York.

Wudianto, R. 1994. Membuat Setek, Cangkok dan Okulasi. Penerbit PT. Penebar SwadayaJakarta.

Yunita, R. 2011. Pengaruh Pemberian Urine Sapi, Air Kelapa dan Rootone F Terhadap Pertumbuhan Setek Tanaman Markisa(Passiflora edulis var. flavicarpa). Solok.Hal 1-10. 